\title{
Volcanism and Earthquakes
}

\section{-Polemical Notes on Mantle Plumes}

\author{
Andrzej Pawuła \\ Member of the Polish Geological Society, Poznań, Poland \\ Email:pawula@amu.edu.pl
}

How to cite this paper: Pawuła, A. (2021). Volcanism and Earthquakes-Polemical Notes on Mantle Plumes. Journal of Geoscience and Environment Protection, 9, 96-110. https://doi.org/10.4236/gep.2021.98006

Received: July 6, 2021

Accepted: August 9, 2021

Published: August 12, 2021

Copyright $\odot 2021$ by author(s) and Scientific Research Publishing Inc. This work is licensed under the Creative Commons Attribution International License (CC BY 4.0).

http://creativecommons.org/licenses/by/4.0/

\begin{abstract}
The article presents new views on volcanism and earthquakes. The problem of the scientific basis for the interpretation of geotectonic theories was discussed. The interpretation of the mantle plume phenomenon according to the theory of expansion and the theory of primal forces of nature is presented. The heat source in the Earth's core is thermonuclear reactions. The cause of earthquakes is not collisions of lithospheric plates, but plasma eruptions. The stresses in the rock mass, causing global fractures, arise due to the increase in the size of nuclides in the process of plasma recombination. The oldest basalts that make up the oceanic plates remain invariably along the shores of continents. The widespread view of the subduction of lithospheric plates and vertical convection cells of rock matter should be regarded as a scientific fiction.
\end{abstract}

\section{Keywords}

Geotectonic Theories, Heat Points, Volcanism

\section{The Cause of Geological Activity in Geotectonic Theories}

The phenomena of geological activity have been interpreted for several decades according to the theory of plate tectonics and global expansion. The inspiration for their appearance on the scientific forum was the discovery of the phenomenon of the increase of oceanic plates. The Plate Tectonics Theory annexed Wegener's hypothesis of continental shifting, leaving other traditional views unchanged. On the other hand, the Theory of Global Expansion drew attention to the increase in the radius of the globe and introduced the concept of the evolutionary cycle of planets to planetary geology. The main difference between these theories is the view on the heat source and the causes of geological activity. The structural assumptions of geotectonic theories are presented in schematic dia- 
grams (Figure 1 and Figure 2).

The journal Nature Reviews Earth \& Environment has published the article "Mantle plumes and their role in Earth processes" (Koppers et al., 2021). The authors are interested in the phenomenon of hot spots in the Earth's mantle, which, according to the theory of plate tectonics, treat as a closed system, not related to the Earth's core. The confrontation of the hypotheses concerning volcanism and earthquakes with the geophysical interpretation of these phenomena shows numerous inconsistencies and even contradictions with reality. The view on subduction of assessment plates and remelting rocks in convection cells is not confirmed either in models of rock mass mechanics or in geochronological analyzes.

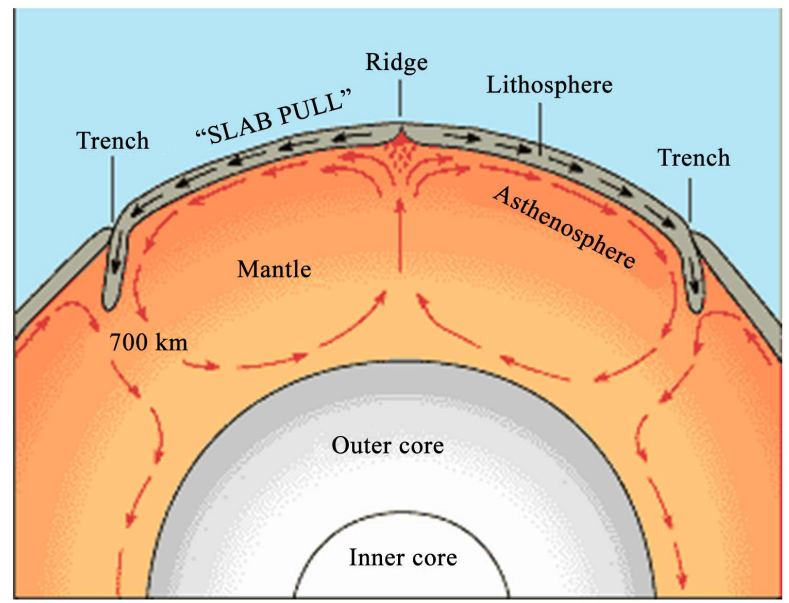

Figure 1. The ideological model of the theory of plate tectonics https://en.wikipedia.org/wiki/Plate_tectonic.

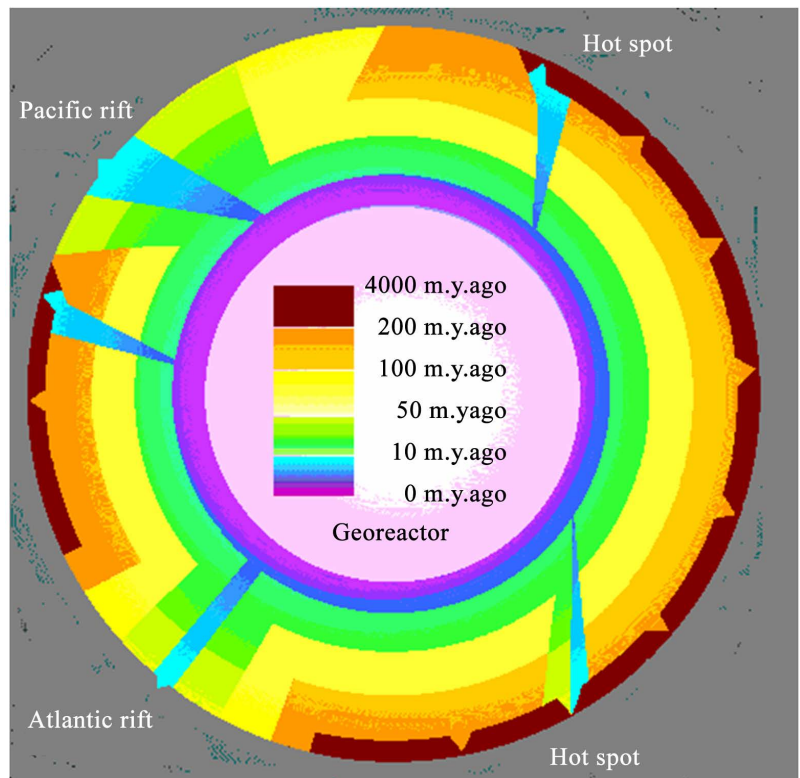

Figure 2. The ideological model of an expanding Earth https://www.nationalgeographic.org/tickets/events/. 
The abundance of publications on mantle plumes indicates numerous attempts to explain the emerging contradictions rather than reports confirming the phenomenon of subduction. Only the image of the global geothermal stream developed in the 1990s (Pollack et al., 1993). The total heat flux of the Earth is approx. $3.8 \times 10^{13} \mathrm{~W}$, which corresponds to an average flux density of $70 \mathrm{~mW} \cdot \mathrm{m}^{-2}$. On continents, the average geothermal flux density is $56 \mathrm{~mW} \cdot \mathrm{m}^{-2}$, while in the ocean rift zone it increases to $350 \mathrm{~mW} \cdot \mathrm{m}^{-2}$ (Figure 3).

According to the theory of plate tectonics, phenomena of geological activity such as earthquakes, volcanoes, and ocean trenches are the result of plate collisions. The basis of the theory of plate tectonics is the assumption that tectonic plates slide along the liquid asthenosphere, which causes collision situations.

\section{Criticism of the Rock Cycle Hypothesis and Lithospheric Plate Subduction}

The fire plume hypothesis appeared along with the plate tectonics theory to fill the gap in this theory. The plate tectonics theory proposed only two types of volcanism, in the ocean fracture zone and in the plate-sump zone. A chain of islands such as Hawaii has become an example of a mantle plume hot spot. In the process of hypothetical subduction, the rocks heat up and as magma return to the eruption zone, creating a so-called rock cycle. The plate tectonics theory explains volcanic activity in the ocean rift zone and in the plate subduction zone by stresses caused by convection currents in the asthenosphere. In the subduction zone, convective currents change their direction to the descending one, why? If the convection current in the rift zone spreads horizontally in the asthenosphere, it cannot simultaneously cause the rift of the ocean plate. If the magma in the rift zone forms an ocean plate, the same magma cannot remain liquid and be subject to downdraft! Mantle plumes are regarded as "deflected by large-scale mantle flow" mobile hotspots. The assumption of the probability of mobility of mantle plumes excludes the connection of this phenomenon with the

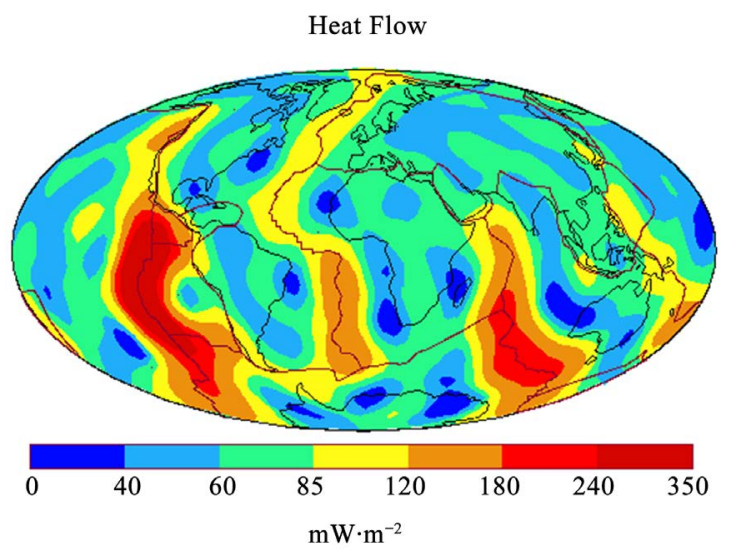

Figure 3. Geothermal flux density (Pollack et al., 1993)

https://www.open.edu/openlearn/nature-environment/environmental-studies/understan ding-deep-geothermal-energy/content-section-1. There are generally two geothermal zones: 1) Cool zone of continental plates; 2) Warm zone of oceanic plate. 
heat source in the Earth's core. The sequence of such hot spots can be explained by a crack and the formation of an eruption rift. Obvious contradictions resulting from the attempt to reconcile the horizontal transport pattern of rock matter as suggested by the theory of plate tectonics are planned to be clarified in an extended program of geochemical, isotopic and geochronological studies.

According to the criteria of rock mass mechanics and geochronological analyzes, it results that convective cells of rock matter do not exist and the subduction of lithospheric plates is fiction. There are no such forces that would force matter to circulate and melt old rocks. The evidence that basalt magma is freshly formed matter is the result of geochronological analyzes. At the exflow site, the basalt lava has a zero age (Figure 3). Confirmation of the juvenility of this magma is its homogeneous and unchanging mineral composition. A comparison of the age of the oldest recordings at the edges of continents with the age of the appearance of the ocean rift indicates that the speed of continental retreat is the same as the speed of ocean plate growth, so these speeds are balanced. The Middle Jurassic basalts that started the formation of the oceanic plate are still in the same place and have not pressed an inch under the continental plate. In the schematic diagram of the plate tectonics theory, there is no explanation for volcanism in the middle of the continents, and therefore also for hot spots, which are a signal of a waking volcano.

\section{The Complex Nature of Geological Processes}

In order to explain the phenomenon of volcanism inside the continents, seismological studies of the volcanoes of the Central Massif in France were undertaken. It was found that continental volcanoes are not related to plate subduction and convection cells, on the contrary, they are stationary and their roots reach the $\mathrm{D}$ zone (Figure 4).

The expansion theory states that the radius of the Earth is growing and those magmatic intrusions are formed in the mantle as a result of processes taking place in the Earth's core (Terez et al., 2013). The hot spots have their heat source in the Earth's core (Figure 5). The search for vertical convective cells of rock matter has no physical justification. The logical conclusion was the postulate of magma formation in the D zone, which was formulated in 2000 at a scientific meeting of the Polish Geological Society (Pawuła, 2000).

The expansion theory takes into account the fact that the Earth is a planet and its history is part of the evolution of the solar system. The theory of the expansion of the Earth is related to the logic of the theory of primal forces of nature, which is expressed in the evolution of the planetary sequence (Pawuła, 2021a). The processes taking place in this evolutionary sequence of the Earth are gravitational accretion causing the increase in mass and temperature increase of the globe, ionization of matter and the formation of low-temperature plasma, then the spontaneous formation of a thermonuclear reactor and the production of hot plasma, and finally the recombination of hot plasma and the formation of basalt magma (Pawuła, 2021b). 


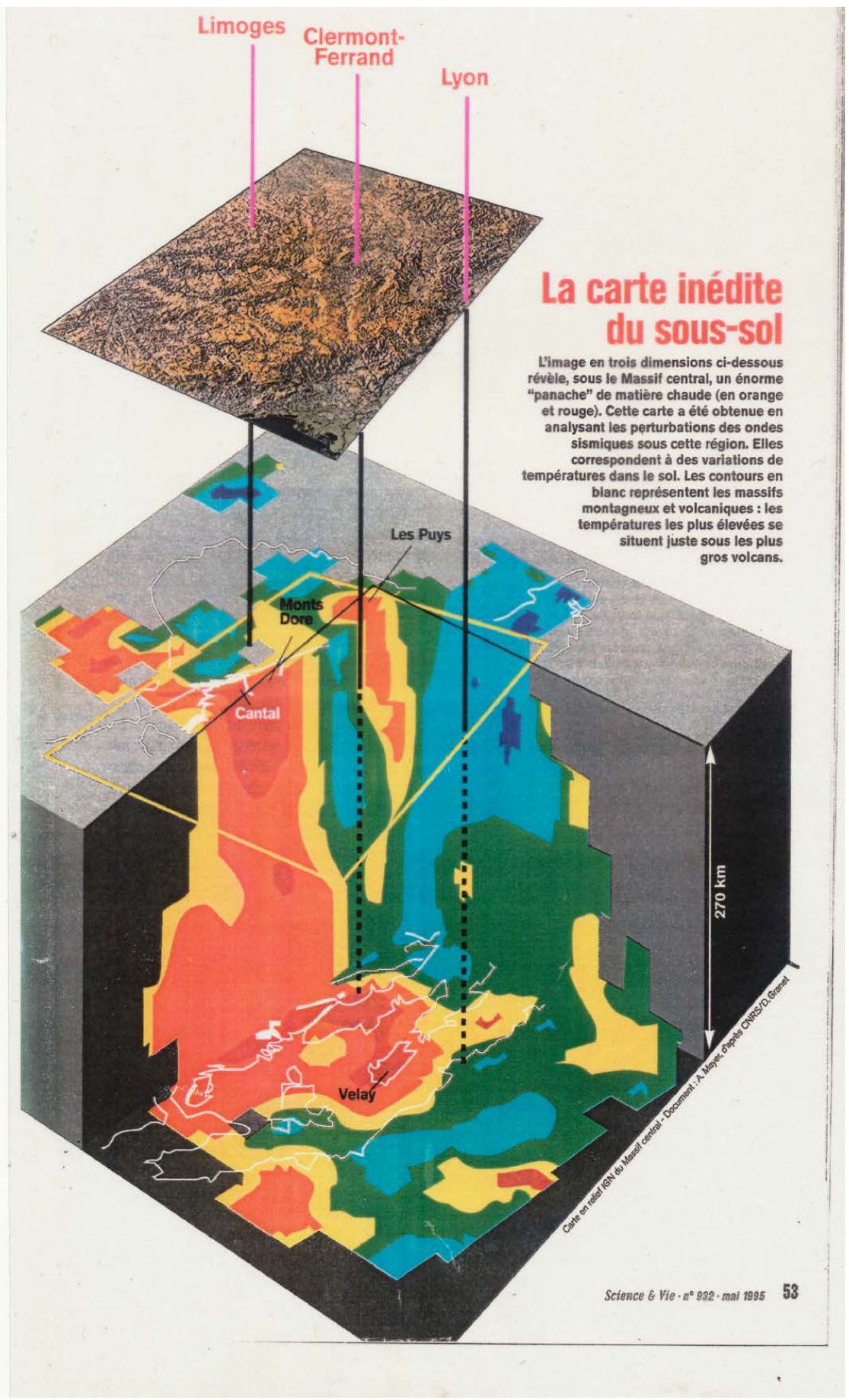

Figure 4. Geophysical model of a hot matter plume. (Roots of the Central Massif volcanoes) (Guillemot, 1995).

The appearance of basalt magma is a special phenomenon related to the expansion of the Earth. The creation of basalt magma is a complex process that requires an explanation of the apparent paradox-the operation of a thermonuclear georector without the expansion of the globe and the expansion of the Earth without increasing its mass. 


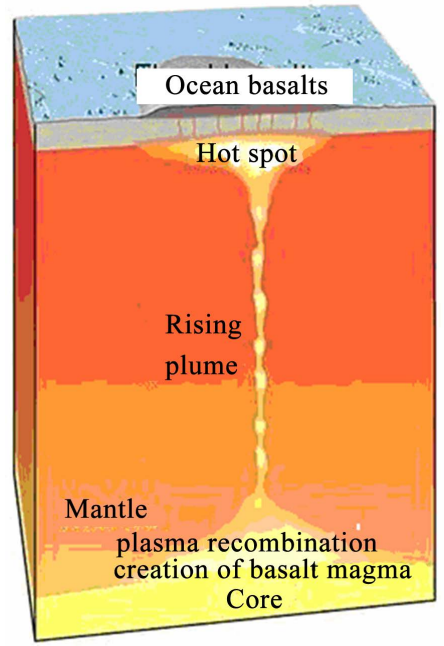

Figure 5. Mantle plumes.

Basalt magma is a product of thermonuclear reactions and has special properties, it contains a complete set of natural elements, is homogeneous and unchanging. It was the same several hundred million years ago when basalt covers formed in Siberia, as during the formation of basalt covers on the Moon. Moreover, fresh basalt (ocean) lava shows zero age in geochronological analyzes. So it is clear evidence of basalt magma in the same thermonuclear process.

An important observation is when the basalt magma erupted and the formation of the basalt trap began around 280 million years ago. The first signs of geological activity in the form of a magnetic field and geothermal phenomena date back to around 3 billion years BP. The question is, why did ocean expansion and plate formation appear so late in Earth's history? The answer should be sought in the phenomenon of the formation of a fusion reactor and geothermal stages of plasma production.

The Earth's evolutionary cycle begins with the gravitational accretion of galactic matter and the formation of planetesimals within the solar system. As the mass of the globe grows, gravitational pressure and consequently temperature increases. The energy of cosmic rays and radiogenic heat of radioactive elements contribute to the increase in the temperature of the globe. The ionization process is the effect of energy interactions on matter. Initially, a low-temperature plasma is formed, in which the eddy currents generate a magnetic field. The constant increase in temperature, under the conditions of the insulating effect of the magnetic shield, causes the synthesis reactions of plasma nuclides. In thermonuclear reactions, hot plasma is created, the components of which are all natural nuclides, with a predominant proportion of protons (Figure 6).

The expansion of the Earth begins only when the pressure in the reactor exceeds the compressive forces and magnetic sheaths of the reactor chamber. In the case of the Earth, the appearance of the phenomenon of expansion can be estimated at around 500 million years. The exponential increase in the radius of the globe and the marked increase in basalt magma occurred about 280 million 


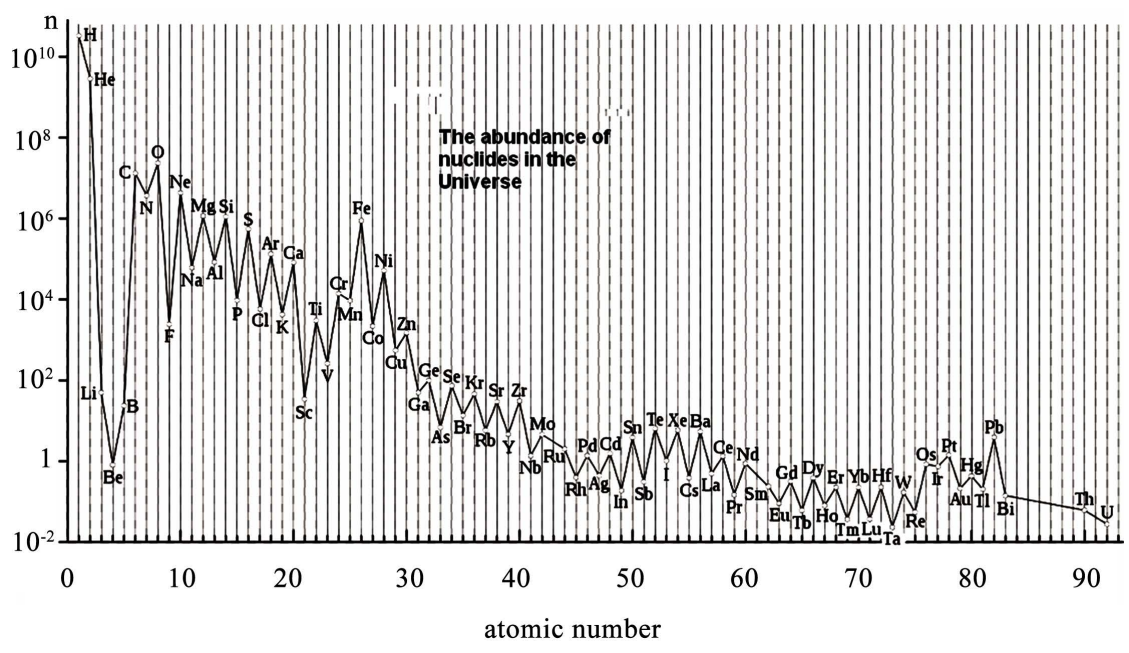

Figure 6. Composition of hot plasma produced in spontaneous thermonuclear reactors.

years ago. The formation of oceanic plates occurred 100 million years later (Figure 7). The increase in basalt magma and the expansion of the Earth will be explained by the phenomenon of plasma recombination, i.e. the transformation of ionized matter into atomic matter.

In conditions of high temperature of the plasma of the thermonuclear georeactor, when the plasma pressure exceeds the gravitational pressure and magnetic attraction forces, the plasma spouts outside the core, into the $\mathrm{D}$ zone privileged zones as indicated by ocean rifts. In the D zone, in a mixture of free ions and electrons, the formation of elements takes place. The recombination process consists of catching electrons and placing them in specific orbits. The process of creating elements is expressed by changing the electromagnetic properties and the structure of matter particles. In the recombination process, the volume of elements increases. The formation of elements is manifested by an increase in the volume of matter without changing the mass. The mass of electrons is negligibly small in relation to the mass of ions (Pawuła, 2021c).

In the case of a proton having a diameter, a hydrogen atom is formed with a diameter. In order to imagine the phenomenon of an increase in the volume of a matter particle by $10^{15}$ times, it is necessary to recall the molecular forces of freezing water (Figure 8).

Nuclide recombination: Transformation of a nuclide, a positively charged ion, into an electrically neutral element

$$
\mathrm{p}+\mathrm{e}^{-} \rightarrow{ }_{1}^{1} \mathrm{H} .
$$

The material that is formed in the recombination process, at a depth of 2900 $\mathrm{km}$, has a temperature of $3000 \mathrm{~K}\left(3273^{\circ} \mathrm{C}\right)$ (Figure 9). Basalt magma that forms on the surface has a temperature of $1250^{\circ} \mathrm{C}$ and is a mixture of all the elements. The creation of basalt magma causes the emergence of an expansion force, which is the driving force behind stresses in the earth's crust, the formation of igneous intrusions and post-communal processes. Igneous intrusion which we call fire plumes is formed. 


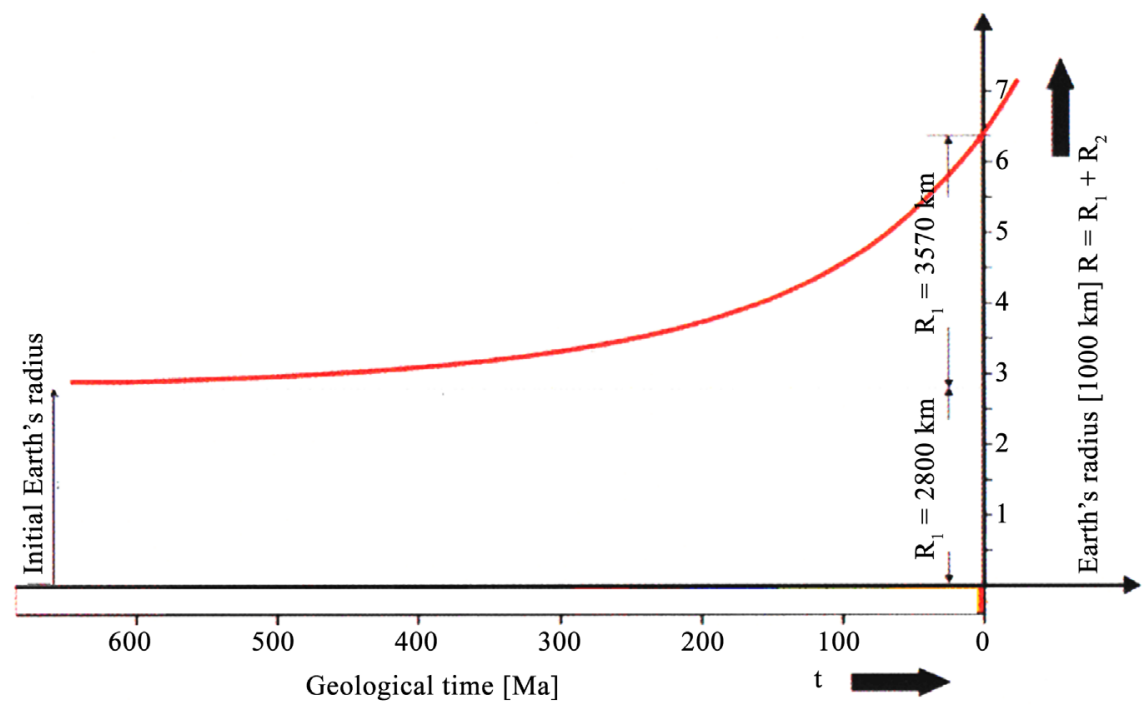

Figure 7. Graph of the Earth's radius growth curve (by Jan Koziar).

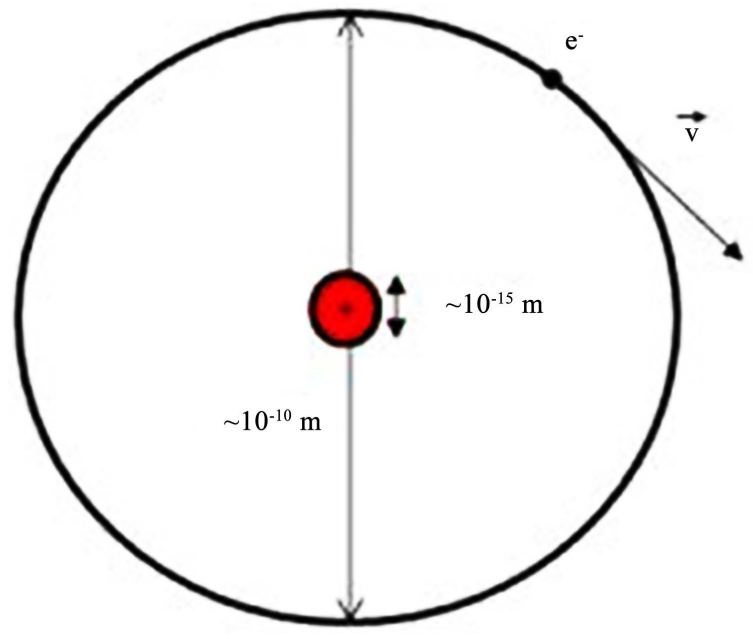

Figure 8. Model of the hydrogen atom.

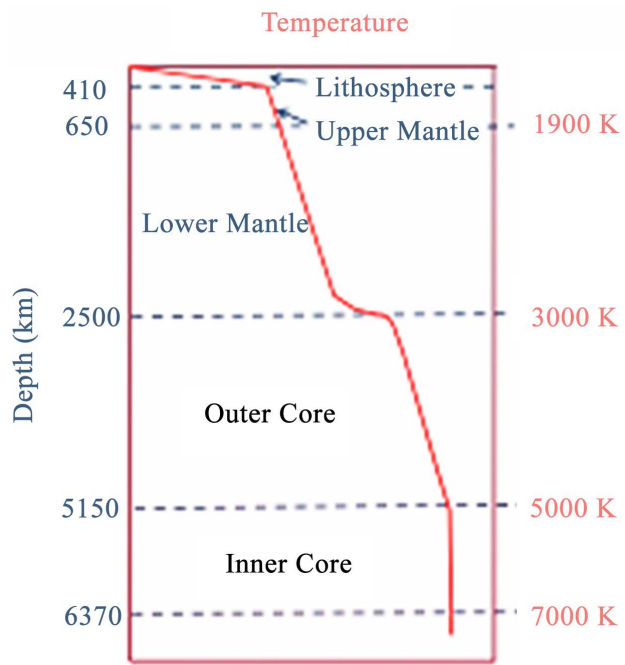

Figure 9. Geothermal profile. 
The phenomenon of expansion occurs during the production of hot plasma, when the surplus of this plasma is thrown outside the core of the planet. The product of the rector's activity is hot plasma, with a composition similar to that of the solar plasma. A characteristic property of hot plasma is the presence of all nuclides with the number of protons from 1 to 92 . In the plasma, the share of single protons is dominant, and in trace amounts, there are nuclides containing 90 and 92 protons. The shield of the reactor is a magnetized layer of low-temperature plasma, about $2000 \mathrm{~km}$ thick.

The enlargement of the matter set-structure creates pressure and enormous pressure of the newly formed magma against the inner wall of the globe. The forces of expanding magma are so great that fractures are formed and basalt magma flows onto the surface of the site. This is already the case on the Moon and Mars (Figure 10).

At temperatures above $1100^{\circ} \mathrm{C}$, basalt magma is still a mixture of elements without the evolution of gases. When magma flows to the surface of the area, it releases magma gases (fumaroles). In the case of basalt magma with a temperature of over $1100^{\circ} \mathrm{C}$, the eruptions are effusive, caused by the structural forces of the matter.

Basalt magma, which does not flow through volcano chimneys and is slowly cooling down, is subject to a differentiation process. Under characteristic temperature conditions, elements and mineral compounds precipitate. In the temperature range of $400^{\circ} \mathrm{C}-900^{\circ} \mathrm{C}$, the pneumatolytic stage takes place, when gases are released from the magma (Figure 11). Hydrogen is the most abundant.

The main cause of geological activity is the thermonuclear processes taking place in the Earth's core and the direction of the flow of matter towards the surface of the globe. As a result of the processes taking place, a geothermal stream is formed, the production of basalt magma, and the formation of mineral deposits. This epochal statement changes the current view that the cause of this activity is only the collision of lithospheric plates and convection currents of rock matter in the Earth's mantle.

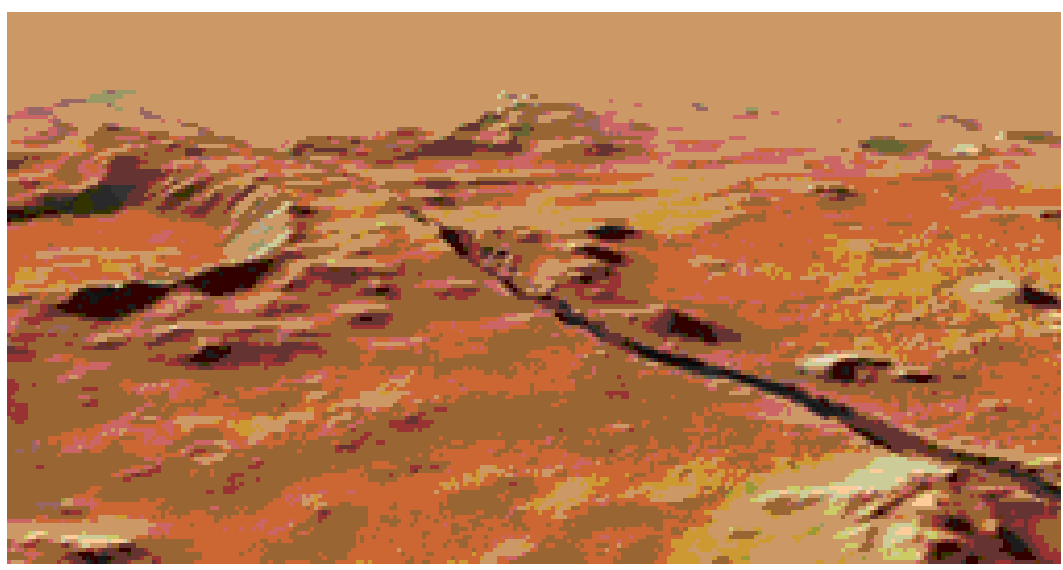

Figure 10. Photo tectonic fault on mars [Region Cerberus Fossae]. NASA in sigh [ESA/DLR/FU Berlin, CC BY-SA3.0 IGO]. 


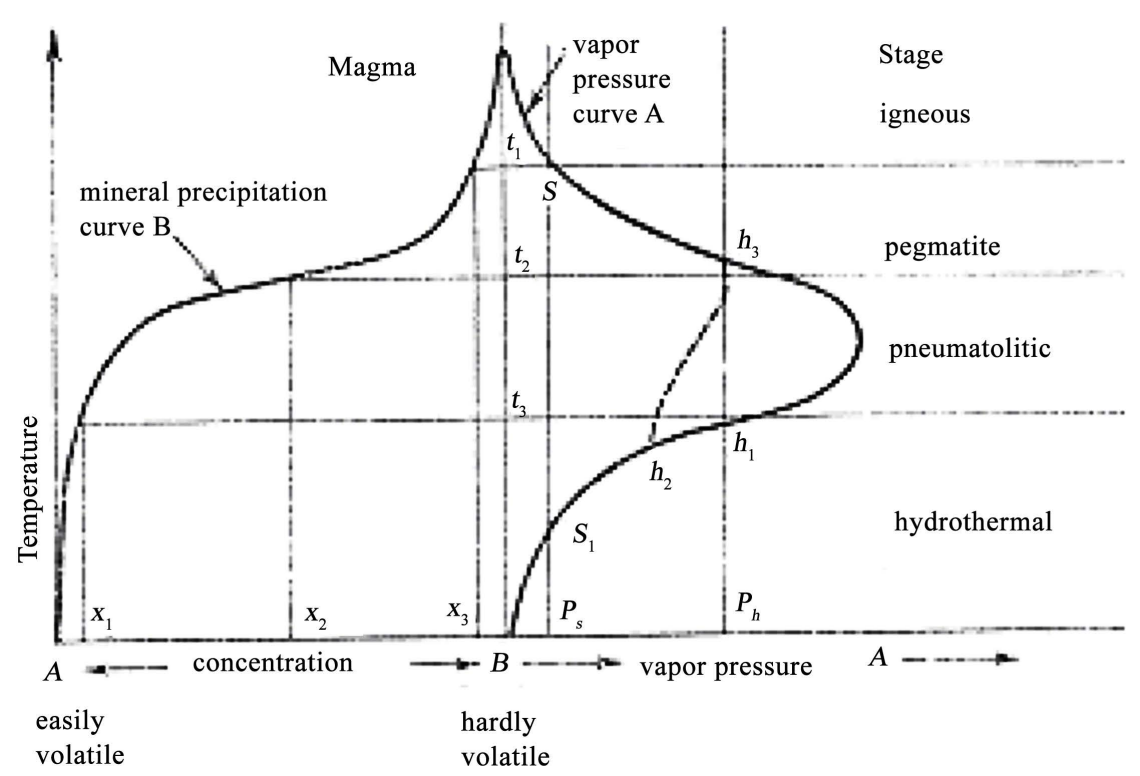

Figure 11. Niggli's post-magmatic stages.

You should be aware of the forces that cause the globe to rupture, to eject magma from a depth of about 3000 kilometers, and in some cases to explode pyroclastic materials to a height of more than 50 kilometers (Figure 12).

The pressure of the expanding magma is the cause of strong seismic shocks. This situation can be explained by the example of catastrophic seismic shocks in the center of the continents (Figure 13). As a result of the plasma ejection, a batolite of basalt magma is formed, the volume of which rapidly increases (Figure 14).

Volcanic eruption is caused by magma pressure, and under certain conditions, igneous gases explode. This has to do with the mineral composition and temperature of the magma. Primary basalt lava in the exuberant volcanoes of Hawaii has a temperature in the range of $1100^{\circ} \mathrm{C}-1250^{\circ} \mathrm{C}$, it is liquid and rich in dark minerals. In explosive volcanoes, lava has a rhyolite mineral composition, is enriched with silica and has a lower temperature, in the range of $750^{\circ} \mathrm{C}-900^{\circ} \mathrm{C}$.

One of the arguments for the origin of basalt magma from the hot plasma of the Earth's core is the elemental composition of magma (Figure 6), similar to the composition of the plasma. Seismic shocks are the result of the recobination of hot plasma and igneous gases. The difference is the hydrogen that is released from the magma. The shock distribution images are characteristic, different for weak tremors with magnitude $\mathrm{M}<5 \mathrm{M}$ (map a) (Figure 15) and for strong tremors, magnitude $>7 \mathrm{M}$ (map b) (Figure 16).

\section{Map a) $M<5$ earthquakes}

1) Deep seismic tremors in the region of oceanic rifts and tectonic ditches, caused by the plasma recombination process and the formation of basalt magma. The high magma temperature maintains the state of the mixture without gas evolution. Basalt magma is liquid and degasses at the earth's surface (exudative volcano). 


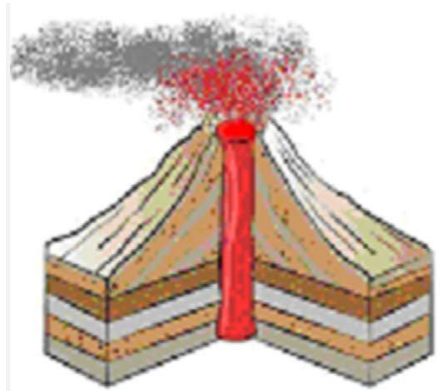

explosive volcano rhyolite lava

temperature $700^{\circ} \mathrm{C}-900^{\circ} \mathrm{C}$

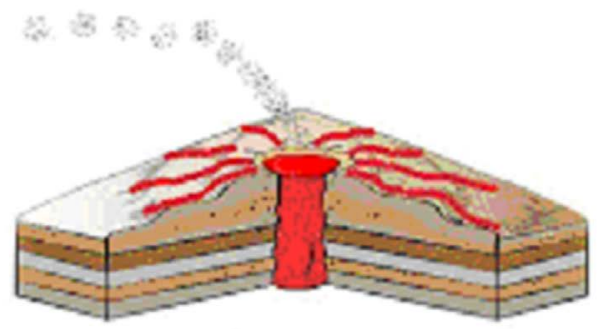

effusive volcano alkaline lava

temperature $1100^{\circ} \mathrm{C}-1250^{\circ} \mathrm{C}$

Figure 12. Extreme types of volcanoes: Explosive and effusive (Orton, 1996) https://niezbednikgeografa.files.wordpress.com/2020/03/18_wuklany.pdf.

USGS Shake Map: EASTERN SICHUAN, CHINA

Mon. May 12, 2008 06: 28.01; GMT M 7.9; N 31.02; E 103.37; Depth. 19.0 km; ID: 2008 ryạn

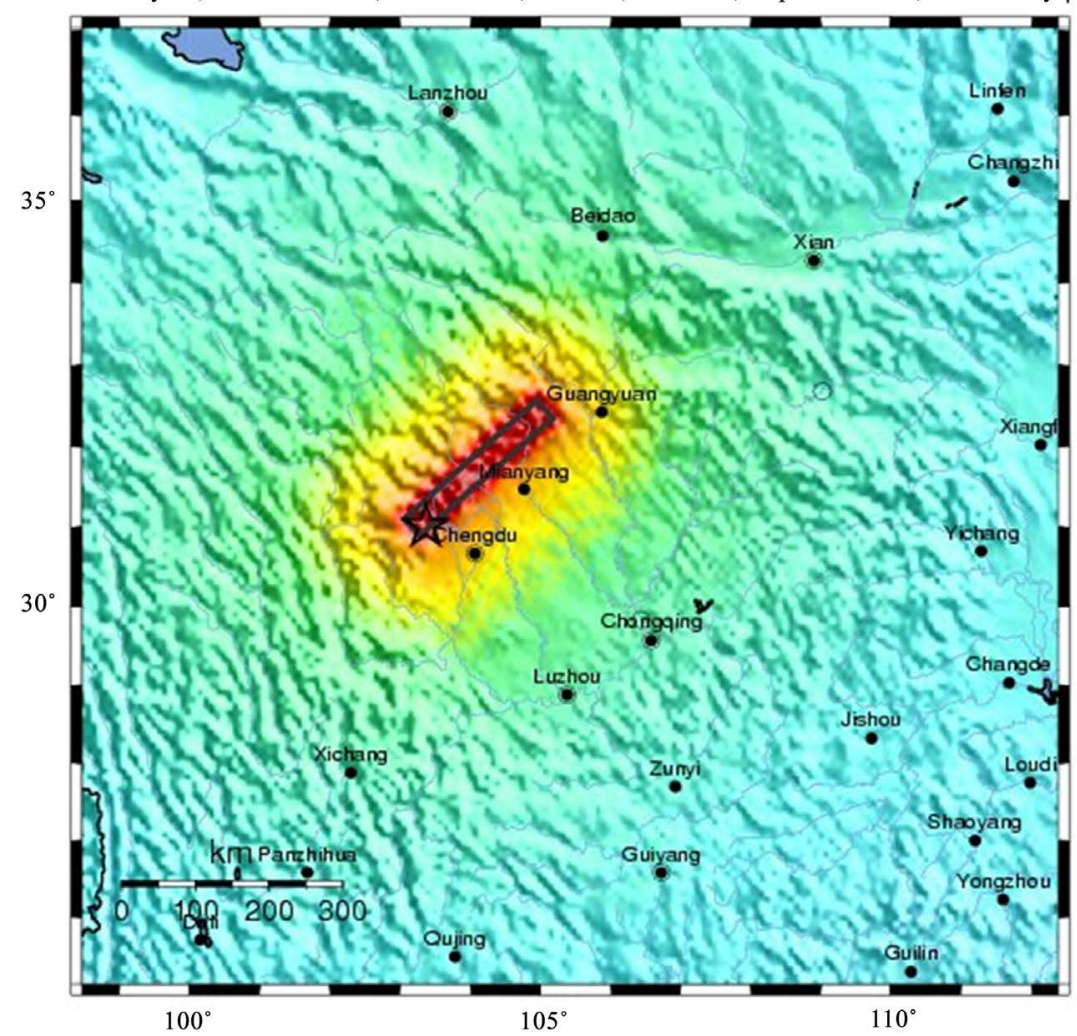

Map Version 7 Processed True May 13, 2008 09:12:25 AM MDT - NOT REVIEWED BY HUMAN

\begin{tabular}{|c|c|c|c|c|c|c|c|c|c|}
\hline $\begin{array}{l}\text { PERCENED } \\
\text { SHAKING }\end{array}$ & Not felt & Weak & Light & Mode rate & Strong & Very strong & Severe & Violent & Extreme \\
\hline $\begin{array}{l}\text { POTENTIAL } \\
\text { DAMAGE }\end{array}$ & none & none & none & Very light & Light & Moderate & $\begin{array}{l}\text { Moderate/ } \\
\text { Heavy }\end{array}$ & Heavy & Very Heavy \\
\hline PEAK ACC. (\%g) & $<.17$ & $.17-1.4$ & $1.4-3.9$ & $3.9-9.2$ & $9.2-18$ & $18-34$ & $34-65$ & $65-124$ & $>124$ \\
\hline PEAK VEL $(\mathrm{cm} / \mathrm{s})$ & $<.1$ & $.1-1.1$ & $1.1-3.4$ & $3.4-8.1$ & $8.1-16$ & $16-31$ & $31-60$ & $60-116$ & $>116$ \\
\hline $\begin{array}{l}\text { INSTRUMMENTAL } \\
\text { INTENSITY }\end{array}$ & I & II - III & IV & $\mathrm{V}$ & VI & VII & VIII & IX & $x+$ \\
\hline
\end{tabular}

Figure 13. Earthquake map. Magnitude 7.9; Chongqing, Region Eastern Sichuan, China 1545 km SW of Beijing, May 12, 2008; Depth 19 km. 


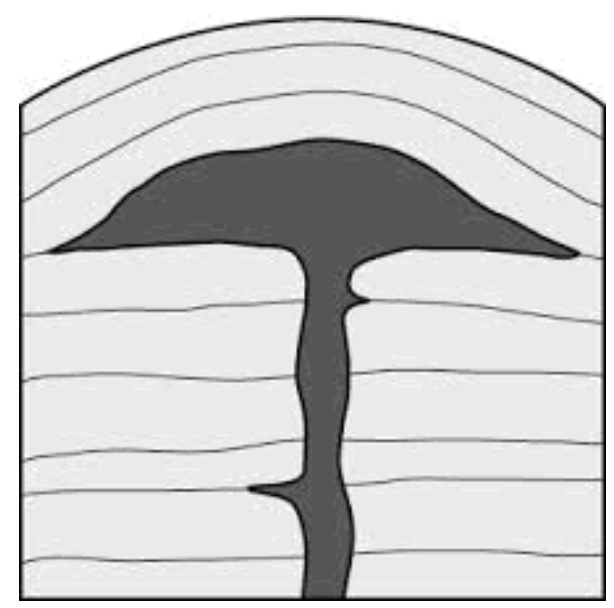

Figure 14. Batolite of swelling basalt magma.

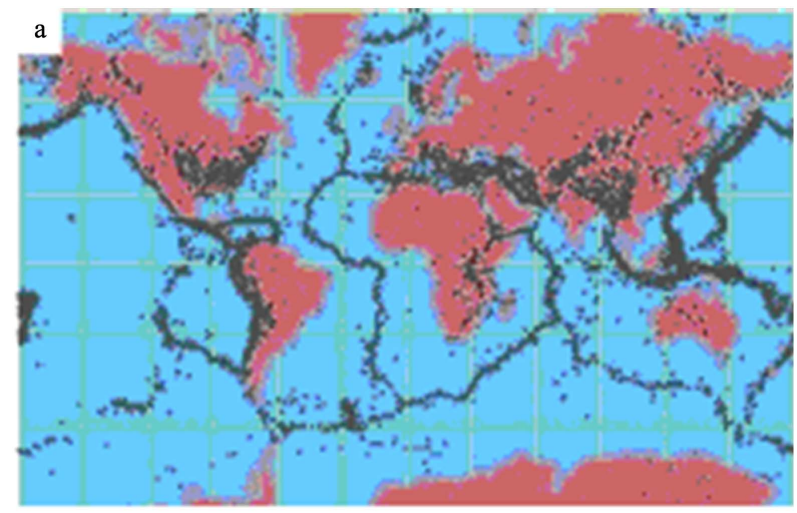

Figure 15. Earthquakes of magnitude $M<5$.

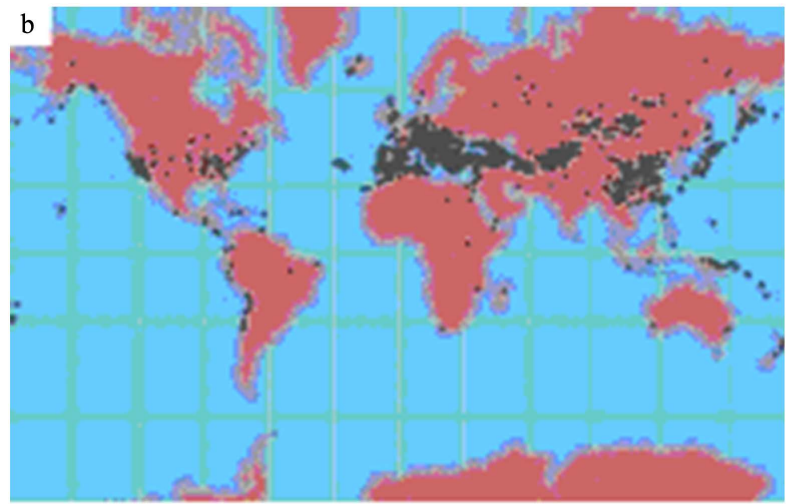

Figure 16. Earthquakes of magnitude $M>7$.

2) Shallow shocks caused by compressive stresses are in the earth's crust.

\section{Map b Earthquakes with magnitude $\mathbf{M}>7$}

Deep seismic shocks. As a result of temperature drop $\left(<900^{\circ} \mathrm{C}\right)$, mafic minerals $(\mathrm{Mg}-\mathrm{Fe})$ precipitate from the magma and form rhyolite magma, enriched in silica, sticky. Gases are released, mainly hydrogen, which reacts with carbon, carbon oxides, sulfur to form methane, water, hydrogen sulfide, etc. Under cer- 
tain conditions, the accumulated hydrogen and methane will explode, causing severe earthquakes (explosive volcanoes).

The result of nuclide recombination is the addition of orbital electrons and the formation of elements. Chemical elements are formed and react with each other. The protons dominating in the plasma form hydrogen gas, which reacts with oxygen and carbon:

$$
\begin{aligned}
& 2 \mathrm{H}_{2}+\mathrm{C} \rightarrow \mathrm{CH}_{4} \\
& 3 \mathrm{H}_{2}+\mathrm{CO} \rightarrow \mathrm{CH}_{4}+\mathrm{H}_{2} \mathrm{O} .
\end{aligned}
$$

In place of protons, hydrogen atoms appear, the volume of which is $10^{15}$ times greater than that of the proton. Describing the phenomenon of recombination, we can say that the change in the electric charge of a matter particle caused the volume of this particle to increase so enormously.

The plasma recombination process causes a sharp increase in pressure, the appearance of tectonic stresses, seismic shocks and volcanic eruptions. The resulting elements form basalt magma, the characteristic feature of which is the stability of the chemical composition and a stable concentration of uranium at the level of $1 \mathrm{ppm}$. Basalt magma contains a wide spectrum of elements, including radioactive heavy metals, uranium, and thorium. Hydrogen reacts with carbon and oxygen to form hydrogen oxide, water and methane. Finally, the main components of volcanic gases are youthful waters from the reaction of hydrogen with carbon monoxide and carbon oxides from the reaction of carbon with oxygen (Table 1). The methane present in the volcanic gas burns violently, increasing the volcanic eruption of the volcano.

The hot magma remaining in zone D presses on the mantle of the globe, causing igneous intrusion and metasomatosis of the encountered rocks. At a temperature of about $900^{\circ} \mathrm{C}$, there is a rapid release of igneous gases. At temperatures $<900^{\circ} \mathrm{C}$, magma gases and auxiliary solutions are released: $\mathrm{CO}_{2}, \mathrm{H}_{2}, \mathrm{HCl}$, $\mathrm{H}_{2} \mathrm{~S}, \mathrm{SO}_{2}, \mathrm{CH}_{4}, \mathrm{H}_{2} \mathrm{O}, \mathrm{NH}_{3}, \mathrm{P}_{4} \mathrm{O}_{10}$. The mineral compounds of silicon, titanium, aluminum, iron, manganese, calcium, sodium, potassium and phosphorus crystallize in the basalt rock, as well as numerous trace elements: basalt magma is an evident evidence of the existence of a thermonuclear georeactor in the Earth's core. The hydrogen gas reacts violently with carbon to form dry methane and with carbon monoxide to form juvenile water and methane. Under high pressure,

Table 1. Chemical composition of volcanic gas-Mont Pélé, Martinique.

\begin{tabular}{cccc}
\hline Component & \% vol. & Component & $\%$ vol. \\
\hline $\mathrm{CO}_{2}$ & 10.1 & $\mathrm{~F}_{2}$ & 3.3 \\
$\mathrm{CO}$ & 2.0 & $\mathrm{Cl}_{2}$ & 0.4 \\
$\mathrm{H}_{2}$ & 0.2 & $\mathrm{HCl}$ & 0.0 \\
$\mathrm{~S}_{2}$ & 0.5 & $\mathrm{~N}+$ rare gases & 0.9 \\
$\mathrm{SO}_{3}$ & - & $\mathrm{H}_{2} \mathrm{O}$ & 82.5 \\
\hline
\end{tabular}

Source: MacDonald G. A., 1972: Volcanoes.Prentice-Hall Inc., New Jersey. 
methane is forced through the rocks of the Earth's mantle and the lithosphere, and during the eruption of igneous gases, it burns violently (explodes).

\section{Conclusions}

In summary, the cause of geological activity, volcanism, and earthquakes is not the collision of continental plates, but the eruption of plasma from the Earth's core and the recombination of nuclides in zone $\mathrm{D}$, the formation of elements takes place. The recombination process, which is expressed in a sharp increase in the size of matter particles, takes place without changing the mass. The expansion of the Earth, which is manifested in the increase of basalt magma in the mantle and ocean plates, takes place without the increase in the mass of the globe. This is confirmed by the fact that a thermonuclear georeactor has been operating for several billion years without the phenomenon of expansion. The main cause of volcanism and earthquakes is the process of creating elements in the Earth's core. The newly formed elements form basalt magma which expands without weight gain. The mantle plumes are fed with hot magma from the Earth's core. On the other hand, a constant increase in the mass of the Earth exists within the planetary evolutionary cycle, which results from the action of the primal forces of nature.

The analysis of earthquake distribution shows that the magnitude of the earthquakes depends on the temperature of the Niggly phase, the type of mag$\mathrm{ma}$, and the degree of degassing of the magma. Under conditions of the continuous eruption of hot and liquid basaltic magma, earthquakes are frequent but weak. As the magma cools down, the mineral composition is differentiated and igneous gases are released. Hydrogen accumulates in gas traps and reacts with other elements. There is, among others, flammable methane. Volcanic eruptions and earthquakes are then irregular, separated by quiet but violent periods.

Igneous solutions exert pressure on the rocks of the mantle and the earth's crust, creating mineral and natural gas deposits. Igneous methane, next to deposits of natural gas and methane hydrates, accumulates in tectonic fissures and is the cause of volcanic explosions.

\section{Conflicts of Interest}

The author declares no conflicts of interest regarding the publication of this paper.

\section{References}

Guillemot, H. (1995). Une gigantesque poche de magma sous l'Auvergne. Science \& Vie, 932, 52-56.

Koppers, A. P., Becker, T. W., Jackson, M. G., Konrad, K., Müller, R. D., Romanowicz, B., Steinberge, B., \& Whittaker, J. M. (2021). Mantle Plumes and Their Role in Earth Processes. Nature Reviews Earth \& Environment, 2, 382-401. https://doi.org/10.1038/s43017-021-00168-6

Orton, G. J. (1996). Volcanic Environments. In H. G. Reading (Ed.), Sedimentary Envi- 
ronments-Processes, Facies and Stratigraphy (pp. 485-567). Blackwell Science Ltd.

Pawuła, A. (2000). Evolution of the Earth in the Light of GPS Measurements (Papers T.IX, pp. 25-38). Polish Geological Society.

Pawuła, A. (2021a). Geologist's Reflections. The Publication Presents New Views on the Evolution of the Earth and the Formation of Mineral Deposits. Lambert Academic Pulishing.

https://www.lap-publishing.com/catalog/details//store/gb/book/978-620-3-92537-1/geo logist-s-reflections

Pawuła, A. (2021b). The Phenomenon of a Natural Thermonuclear Reactor. Journal of Geoscience and Environment Protection, 9, 92-109. https://doi.org/10.4236/gep.2021.92006

Pawuła, A. (2021c). The Problem of Natural Radioactive Elements. Journal of Geoscience and Environment Protection, 9, 176-194. https://doi.org/10.4236/gep.2021.94011

Pollack, H. N., Hurter, S. J., \& Johnson, J. R. (1993). Heat Flow from the Earth's Interior: Analisis of the Global Data Set. Reviews of Geophysics, 31, 267-280. https://doi.org/10.1029/93RG01249

Terez, E. I., \& Terez, I. E. (2013). Thermonuclear Reaction as the Main Source of the Earth's Energy. International Journal of Astronomy and Astrophysics, 3, 362-365. https://doi.org/10.4236/ijaa.2013.33040 